\title{
Populacional structure of Apistogramma agassizii (Steindachner, 1875) (Perciformes: Cichlidae) in aquatic environments of the Amana Sustainable Development Reserve (Amazonas - Brazil)
}

\section{Estrutura populacional de Apistogramma agassizii (Steindachner, 1875) (Perciformes: Cichlidae) em ambientes aquáticos da Reserva de Desenvolvimento Sustentável Amanã (Amazonas - Brasil)}

\author{
Jomara Cavalcante de Oliveira ${ }^{1,2 *}$, Sidinéia Aparecida Amadio $^{2} \&$ Helder Lima de Queiroz $^{1}$ \\ ${ }^{1}$ Instituto de Desenvolvimento Sustentável Mamirauá - IDSM \\ ${ }^{2}$ Coordenação de Pesquisas em Biologia Aquática (CPBA), Instituto Nacional de Pesquisas da Amazônia - INPA \\ *E-mail jomaracoliveira@gmail.com
}

Recebido: 16 de março de 2017 / Aceito: 20 de novembro de 2017 / Publicado: 9 de dezembro de 2017

\begin{abstract}
Apistogramma agassizii is a dwarf cichlid species endemic of the Amazon basin, about which there is little biological and ecological information in their natural habitat, despite their ornamental importance. This study evaluated the populacional structure A. agassizii at Amana Sustainable Development Reserve, Middle Solimões basin, Amazonas, Brazil. Positive sexual dimorphism found is probably related to the reproductive behavior of the species. Some management suggestions are offered to support the sustainable use of the species for the studied sites.
\end{abstract}

Keywords Amazon, cichlids, reproduction.
Resumo Apistogramma agassizii é uma espécie de ciclídeo anão endêmico da bacia amazônica, a qual poucas informações sobre biologia e ecologia são conhecidas para seu habitat natural, apesar de sua importância ornamental. Neste estudo avaliamos a estrutura populacional de A. agassizii na Reserva de Desenvolvimento Sustentável Amanã (RDSA), bacia do Médio Solimões, Amazonas, Brasil. O dimorfismo sexual positivo encontrado provavelmente está relacionado ao comportamento reprodutivo da espécie. Algumas sugestões de manejo são oferecidas para dar suporte ao uso sustentável da espécie nos locais estudados.

Palavras-chave Amazônia, ciclídeos, reprodução.

Financed by Ministério da Ciência, Tecnologia e Inovação MCTI, the Instituto de Desenvolvimento Sustentável Mamirauá - IDSM, INCT Adapta and Coordenação de Aperfeiçoamento de Pessoal de Nível Superior (Capes). 


\section{Introduction}

Acta of Fisheries and Aquatic Resources

The structure of a population includes several attributes among them are the density and place occupied by individuals in the habitat, number of individuals in each age group or size, sex ratio, and morphological differences between individuals of a generation or population (Nikolsky, 1963; Ricklefs, 2013). Studies on the structure of fish populations with ornamental potential are important as they provide information on the ecology of the species in the natural environment as aspects of life strategy for growth and reproduction. In additional, the relationship length-weight of the fish species can be used to estimate the weight of a certain species through the survey on the length of group of individuals, vice-versa (Lemos et al., 2015), collaborating as indirect measure of growth (Gomiero et al., 2010).

The species Apistogramma agassizii (Steindachner, 1875), is widely distributed in the Amazon, it is a small cichlid of freshwater occupying lakes and streams in the Amazon environment. Apistogramma agassizii can reach up to six centimeters in total length, shows sexual dimorphism in adults. The males are larger, more colorful and more prolonged fins with the compared to females (Hercos et al., 2009). The distribution of A. agassizii extends across the South American continent from the foot of the Peruvian Andes to the Amazon delta, localities for members of this complex lie not only in the main river itself, but also in the lower to middle courses of numerous tributaries as well as in the entire drainage region of the Negro river (Römer, 2006).

The Amana Sustainable Development Reserve (RDSA) is located in the mid-Solimões basin $\left(35^{\circ} 43\right.$ "S / $3^{\circ} 16^{\prime} 13^{\prime \prime} \mathrm{W}$ and 6204' 10 " S/ 65'23 '36" W) between the Negro and Japurá river, characterized by white waters. In addition, in the RDSA we find Amana lake, the largest lake in the reserve, reaching approximately $40 \mathrm{~km}$ in length and surface of approximately $100 \mathrm{~km}^{2}$. Amana lake is an environment of black water, but with strong contribution of the white water of the Japura river (Ayres, 1993). In elevated areas of the RDSA there are several strems (igarape, regional name), which form a dense local network of water bodies (Hercos et al., 2009).

In black water environments are found species of small fish and attractive colors that have been targeted by the ornamental trade. Since 1955, when Herbert R. Axelrod discovered and marketed the cardinal tetra, Paracheirodon axelrodi in the middle Rio Negro (Amazonas State), this type of trade has developed considerably (Chao et al., 2001). Anjos et al., (2009) report that approximately 100 million ornamental fish were exported from the Amazon between 2002 and 2005 and the state of Amazonas accounted for about 93\% of Brazilian exports in the period (IBAMA, 2007). The Middle Solimões region stands out for the exploration of ornamental fish exported through the city of Manaus. Export records this region indicate that the discus (Symphysodon aequifasciatus) and species of the genus Apistogramma are the most commonly traded (Mendonça \& Camargo, 2006). The capture and marketing managed ornamental fish has been taking in the Amana Sustainable Development Reserve since late 2008, including S. aequifasciatus and species Apistogramma genus (Hercos et al., 2009).

However, there are still many gaps on the biology and ecology of A. agassizii natural environment. Studies on populacional structure are essential for a better understanding of the species life cycle, and to support the management policies of establishing these fishing resources, contributing to the conservation of stocks.

\section{Material and Methods}

The collect of A. agassizii occurred every two months between January and November 2013, in Amana Lake and Igarapes Cacau and Ubim located in Amana Sustainable Development Reserve (RDSA) (Figure 1). The Amana Reserve is located in the middle Solimões basin ( $1^{\circ} 35$ ' 43 "S / $3^{\circ} 16^{\prime} 13^{\prime \prime} \mathrm{W}$ and $62^{\circ} 44^{\prime} 10^{\prime} / 65^{\circ}$ 23 '36 "W), between the Negro river, black waters and poor in nutrients and the Japurá river, characterized by white or muddy waters, rich in nutrients. In the higher areas of RDSA occur several streams, characterized by a well-defined streambed, forming a dense mesh of water bodies (Hercos et al., 2009).

We used as fishing device the hand net used in the shallow area of the investigated bodies water. The collected samples were dipped in benzocaine hydrochloride solution at a concentration of $250 \mathrm{mg} / \mathrm{L}$ even the total loss of balance (according to Resolution No. 714 of June 2002 the Federal Council of Veterinary Medicine), subsequently immersed in formalin, then in alcohol $70 \%$ and transported to the Laboratório de Ecologia e Biologia de Peixes-ECOBP/IDSM in Tefé-AM, where the sample were measured (standard length, $\mathrm{mm}$ ) and weighed (total weight, g). 
Acta of Fisheries and Aquatic Resources

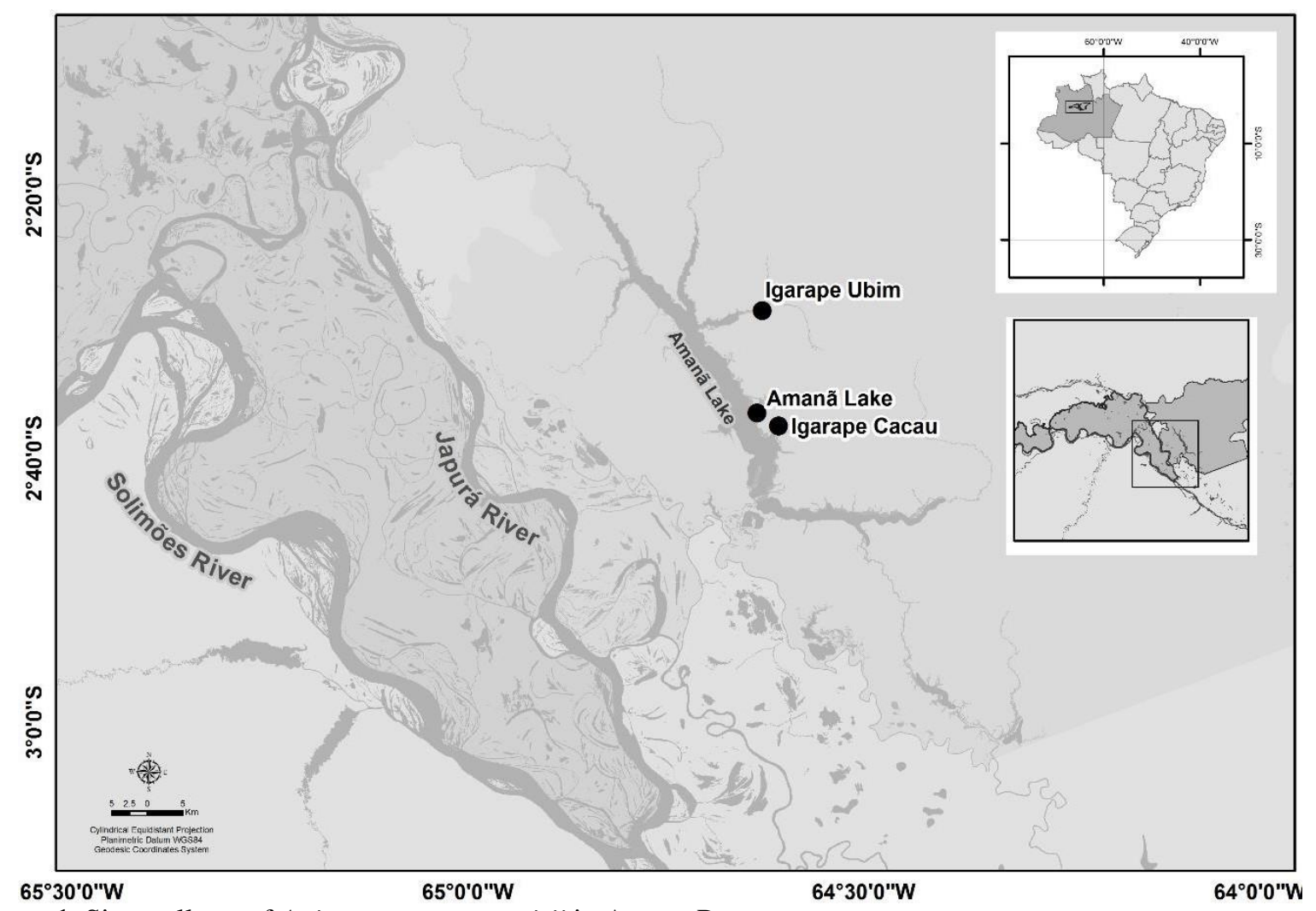

Figure 1. Sites collects of Apistogramma agassizii in Amana Reserve.

The relationship between weight and standard length was established using a linear regression represented by mathematical expression $\mathrm{TW}=\mathrm{a} \times \mathrm{SL}^{\mathrm{b}}$, the total weight data and standard length were logaritmizados and adjusted by the least-squares method for calculating the linear regression where we obtain the values of $b$ (angular coefficient) and the (linear coefficient). The t test was used to verify the existence of significant differences among the $b$ values, when close to isometrics $(b=3)$, respecting the confidence interval of $95 \%$ $(\alpha=0.05)$ (Giarrizzo et al., 2015). The correlation between $\mathrm{W}$ and $\mathrm{L}$ was verified by Pearson analysis through r-squared $\left(\mathrm{r}^{2}\right)$ (Schmidt et al., 2015).

The sex ratio was compared by frequency of occurrence for males and females for each studied area and sampling month. The $\mathrm{G}$ test was applied in order to verify possible differences in the expected ratio of 1: 1 . Significant differences were considered when the calculated value of $\mathrm{G}$ was higher 3.84.

All statistical analyzes were carried out using statistical software BioStat 5.0 (Ayres et al., 2007). Samples of A. agassizii used in this study were collected in the project "Reproductive Biology Apistogramma" whose procedures were approved by the Ethics Committee on Animal Use and Plants for Sustainable Development Mamirauá Institute, with the protocol number CEUAP IDSM-003 / 2013.

\section{Results}

During the study period 900 specimens were captured, 300 of these were from Amana lake, 300 Igarape Ubim and 300 Igarape Cacau. Males and females of the Amana lake and igarape Ubim showed significant difference between the relationship of weight and length, as evidenced by the values of the intercepts (a), indicating sexual differentiation in the increase in length or weight (Table 1). When compared the relationship of weight and length of the specimens with different sites, we observed significant differences in all sites. The males were always greater in length and weight than females, featuring one of the most important aspects of sexual dimorphism of $A$. agassizii. 
Acta of Fisheries and Aquatic Resources

Table 1. Parameters of the linear regressions of standard length (SL) and total weight (TW) of females and males of Apistogramma agassizii. $\mathrm{N}=$ number of samples; $\mathrm{a}=$ numerical value of the intercept; $\mathrm{b}=$ coefficient of regression; $\mathrm{T}_{\mathrm{a}}$ $=\mathrm{t}$ test between the intercepts; $\mathrm{T}_{\mathrm{b}}=\mathrm{t}$ test between the regression coefficients; $\mathrm{r}^{2}=$ coefficient of determination; $\mathrm{r}=$ correlation coefficient. $\mathrm{t}$ test, $5 \%$.

\begin{tabular}{|c|c|c|c|c|c|c|c|}
\hline \multicolumn{8}{|c|}{ Parameters of the equation $\mathrm{TW}=\mathrm{a} \times \mathrm{SL}^{\mathrm{b}}$} \\
\hline Amana lake & $\mathrm{N}$ & a & $\mathrm{T}_{\mathrm{a}}$ & $\mathrm{b}$ & $\mathrm{T}_{\mathrm{b}}$ & $\mathrm{R}^{2}$ & $\mathrm{R}$ \\
\hline Female & 151 & -5.1742 & \multirow{2}{*}{0.0125} & 3.3828 & \multirow{2}{*}{0.1143} & 0.955 & $\underline{0.9773}$ \\
\hline Male & 149 & -5.0324 & & 3.2649 & & 0.9754 & 0.9876 \\
\hline Igarape Cacau & $\mathrm{N}$ & $\mathrm{a}$ & $\mathrm{T}_{\mathrm{a}}$ & $\mathrm{b}$ & $\mathrm{T}_{\mathrm{b}}$ & $\mathrm{R}^{2}$ & $\mathrm{R}$ \\
\hline Female & 152 & -4.8723 & \multirow{2}{*}{0.6923} & 3.1556 & \multirow{2}{*}{0.2198} & 0.9794 & 0.9897 \\
\hline Male & 148 & -4.9712 & & 3.2321 & & 0.972 & 0.9859 \\
\hline Igarape Ubim & $\mathrm{N}$ & $\mathrm{a}$ & $\mathrm{T}_{\mathrm{a}}$ & $\mathrm{b}$ & $\mathrm{T}_{\mathrm{b}}$ & $\mathrm{R}^{2}$ & $\mathrm{R}$ \\
\hline Female & 167 & -4.9093 & \multirow{2}{*}{0.0367} & 3.1873 & \multirow{2}{*}{0.5682} & 0.9185 & $\underline{0.9584}$ \\
\hline Male & 133 & -4.8547 & & 3.1365 & & 0.967 & 0.9834 \\
\hline
\end{tabular}

The sex ratio, considering the total number of specimens was 1 male: 1 female. However, we observed some significant differences in sex ratio when the data were analyzed throughout the study period, when there was a predominance of females relative to males for a few months of collection (Figure 2, Table 2,)
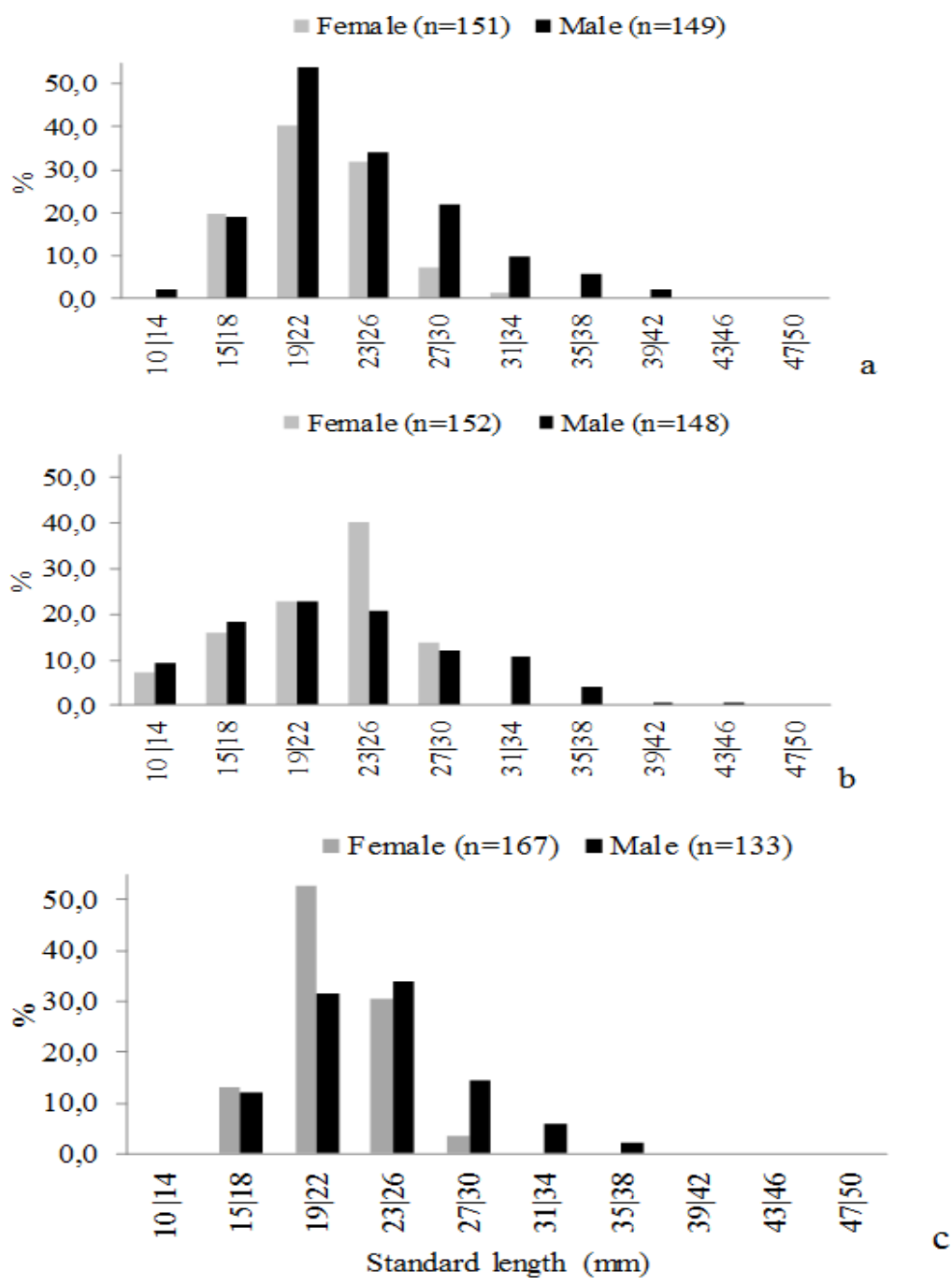

Figure 2. Size distribution by standard length classes of females and males of Apistogramma agassizii (a) Amana lake (b) igarape Cacau and (c) igarape Ubim. 
Acta of Fisheries and Aquatic Resources

Table 2. Sex ratio of Apistogramma agassizii for each collect site. ${ }^{*} \mathrm{G}$ test, significant $\mathrm{G}>3.84, \mathrm{p}<0.05$.

\begin{tabular}{lcccc|ccccccccc}
\hline $\begin{array}{l}\text { Months } \\
\text { samples }\end{array}$ & Female & Male & $\begin{array}{l}\text { Proportion } \\
\text { F:M }\end{array}$ & G test & Female & Male & $\begin{array}{l}\text { Proportion } \\
\text { F:M }\end{array}$ & G test & Female & Male & $\begin{array}{l}\text { Proportion } \\
\text { F:M }\end{array}$ \\
\hline January/13 & 30 & 20 & 1.50 & $10.54^{*}$ & 26 & 24 & 1.08 & 1.35 & 39 & 11 & 3.55 & $26.31^{*}$ \\
\hline March/13 & 30 & 20 & 1.50 & $10.54^{*}$ & 23 & 27 & 0.85 & $-4.44^{*}$ & 19 & 31 & 0.61 & $-14.50^{*}$ \\
\hline May/13 & 18 & 32 & 0.56 & $-12.07^{*}$ & 20 & 30 & 0.67 & $-9.45^{*}$ & 27 & 23 & 1.17 & -1.64 \\
\hline June/13 & 26 & 24 & 1.08 & 1.69 & 24 & 26 & 0.92 & -2.60 & 30 & 20 & 1.50 & $4.49^{*}$ \\
\hline September/13 & 26 & 24 & 1.08 & 1.69 & 36 & 14 & 2.57 & $25.3^{*}$ & 27 & 23 & 1.17 & -1.64 \\
\hline November/13 & 21 & 29 & 0.72 & $-7.60^{*}$ & 23 & 27 & 0.85 & $-4.44^{*}$ & 25 & 25 & 1.00 & $-5.36^{*}$ \\
\hline Total & 151 & 149 & 1.01 & 2.43 & 152 & 148 & 1.03 & 2.74 & 167 & 133 & 1.26 & 3.82 \\
\hline
\end{tabular}

\section{Discussion}

The presence of males larger than females in all environments studied, is the highest expression of sexual dimorphism by A. agassizii (Nikolsky, 1963), as well as other differences already described, such as the morphology of the fins and body color (Chellappa et al., 2005; Ismiño \& Padilla, 2005). These characteristics can be decisive in courtship processes and mating, particularly during the breeding season, since larger males tend to win aggressive encounters with other males, keeping territories of better quality and more access food (Cacho et al., 2006).

The length-weight relationship describes the ways of growth in the different stages of the life cycle of the fish species, which becomes a good indicative of the food and reproductive activities (Silva Júnior et al, 2007). Le Cren (1951) indicate out that the $b$ values for fish may range from 2.5 to 4.0 , but they usually show an isometric growth around 3.0. Therefore, when $b=3$, the species has an isometric growth, where the weight increases proportionally with the length. However, when $b<3$, the growth is negative allometric which indicates that the increment occurs due to the weight, and when $b>3$, the growth is positive allometric, and the increment in the length is higher than the weight. These differences which occur around the allometric coefficient may be related to the biological aspects which characterize the specie, as the different environmental and food variation of the enviromental where they reside (Silva et al., 2005), since they were collected from different places and environments (lake and igarape/stream), consequently differences in growth was be observed.

The sex ratio vary along the life cycle due to successive events that act differently on the individuals of each sex, as the mortality be her caused by natural factors or fishing events, determine the predominance of individuals from one of the sex or different stages of development. (Vazzoler, 1996; Nascimento et al., 2012). During the study we observed the sexual ratio of 1: 1 , but in detailed analyzes changes were observed in this proportion, indicating the predominance of females in different length classes or at different times of the study.

Therefore, the significant proportion of females observed during the study for the collect sites, can probably be related to the fact that these sites in the years prior to this study, there was the ornamental fishing A. agassizii. During the ornamental fishing had preference for male individuals, because morphologically are larger and more colorful than females, showing greater interest in the ornamental market. Consequently, this selection by males may have contributed to the higher proportion of female A. agassizii.

\section{Acknowledgements}

We thank the Ministério da Ciência, Tecnologia, Inovação e Comunicação - MCTIC, the Instituto de Desenvolvimento Sustentável Mamirauá - IDSM, and the INCT ADAPTA, by the financial support. The Coordenação de Aperfeiçoamento de Pessoal de Nível Superior (CAPES) for granting master's scholarship. We are also grateful to all assistants, all were essential for implementation of this project. 


\section{References}

Alves, F. C. M., Rojas, N. E. T., \& Romagosa, E. (2009). Reprodução do "Cíclídeo-Anão Amazônico", Apistogramma cacatuoides, Hoedeman, 1951 (Perciformes: Cichlidae) em laboratório. Boletim Instituto de Pesca, 35(4): 587-596,

Anjos, H. D. B.; Amorim, R. M. S.; Siqueira, J. A. \& Anjos, C. R. (2009). Exportação de peixes ornamentais do estado do Amazonas, Bacia Amazônica, Brasil. Boletim do Instituto de Pesca, 35(2): 259-274,

Aranha, J. M. R., \& Caramaschi, E. P. (1999). Estrutura populacional, aspectos da reprodução e alimentação dos Cyprinodontiformes (Osteichthyes) de um riacho do sudeste do Brasil. Revista Brasileira de Zoologia, 16(3), 637-651.

Araújo, A. S., Nascimento, W. S., Yamamoto, M. E., \& Chellappa, S. (2012). Temporal dynamics of reproduction of the neotropical fish, Crenicichla menezesi (Perciformes: Cichlidae). The Scientific World Journal, 2012, 1-10.

Ayres, J. M. (1993). As matas de várzea do Mamirauá: médio rio Solimões. Rio de Janeiro, CNPq/ PTU, SCM, 1993.

Ayres, M., M. Ayres Jr., D. L. Ayres \& A. S. Santos (2007). BioEstat 5.0: Aplicações Estatísticas nas Áreas das Ciências biológicas e Médicas. Instituto de Desenvolvimento Sustentável Mamirauá. MCt/ Cnpq. Belém.

Cacho, M. S. R. F.; Chellappa, S. \& Yamamoto, M. E. (2006). Reproductive success and female preference in the Amazonian cichlid angel fish, Pterophyllum scalare (Lichtenstein, 1823). Neotropical Ichthyology, 4(1): 87-91,

Chao, N. L. The fishery, diversity, and conservation of ornamental fishes in the Rio Negro Basin, Brazil - a review of Project Piaba (1989- 99). 2001. In: Chao, N. L.; Petry, P.; Prang, G.; Sonneschien, L. \& Tlusty, M. (Eds.). Conservation and management of ornamental fish resources of the Rio Negro Basin, Amazonia, Brazil - Project Piaba. Manaus: Editora da Universidade do Amazonas, pp.161-204.

Chellappa, S; Câmara, M. R. \& Verani-Jr. (2005). Ovarian development in the Amazonian red discus Symphysodon discus Heckel (Osteichthye: Cichlidae). Braz. J. Biol., 65(4):609-616.

Einum S. \& Fleming I.A. (1999) Maternal effects of egg size in brown trout (Salmo trutta): norms of reaction to environmental quality. Proceedings of the Royal Society: Series B, 266, 2095-2100.

Giarrizzo, T., Oliveira, R.R.S., Andrade, M.C., Gonçalves, A.P., Barbosa, T.A.P., Martins... \& Sousa, L.M. (2015). Weight and length length relationships for 135 species of fish from the Xingu River (Amazon Basin, Brazil). J. Appl. Ichthyol., 31(2): 415-424.

Gomiero, L.M., Villares-Junior, G.A. \& Braga, F.M.S. (2010). Relação peso-comprimento e fator de condição de Oligosarcus hepsetus (Cuvier, 1829) no Parque Estadual da Serra do Mar-Núcleo Santa Virgínia, Mata Atlântica, estado de São Paulo, Brasil. Biota Neotropica, 10(1): 101-105.

Hercos, A. P.; Queiroz, H. L. \& Almeida, H. L. Peixes Ornamentais da Reserva Amanã. Tefé: IDSM, 2009.

Ibama) Instituto Brasileiro do Meio Ambiente e dos Recursos Naturais Renováveis (2007). Relatório

Técnico sobre o Diagnóstico geral das práticas de controle ligadas a exploração, captura, comercialização, exportação e uso de peixes para fins ornamentais e de aquariofilia - Diretoria de uso sustentável da biodiversidade e florestas. Brasília: Ibama.

Ismiño R. \& Padilla P. (2005). Comportamiento reproductivo de cinco especies del gênero Apistogramma (Cichlidae) en ambientes controlados. pp. 222-226. In: Biología de las Poblaciones de Peces de la Amazonía y Piscicultura. Lima: IIAP-Iquitos/IRD - Paris.

Mendonça, M.; Camargo, M. (2006). Etnoecologia da produção de peixes ornamentais num Setor do Médio Rio Solimões, Flona de Tefé e Reservas Mamirauá e Amanã - Estado do Amazonas. Uakari. 2(1) 53-61.

Le Cren, E.D. (1951). The length-weight relationship and seasonal cycle in gonadal weight and condition in the perch (Perca fluviatilis). J. An. Ecol., 20(2): 201-219

Lemos, J.R.G., Oliveira. A.T., Santos, M.Q.C., Pereira, C.N., Nascimento, R.B. \& Tavares-Dias, M. (2015). Influência do transporte na relação peso-comprimento e fator de condição de Paracheirodon axelrodi (Characidae). Biota Amazonia, 5(4): 22-26.

Nascimento, W. S., Yamamoto, M. E., \& Chellappa, S. (2012). Proporção sexual e relação pesocomprimento do peixe anual Hypsolebias antenori (Cyprinodontiformes: Rivulidae) de poças temporárias da região semiárida do Brasil. Biota Amazonia, 2(1), 37-44.

Nikolsky, G. V. 1963. The ecology of fishes. London, Academic Press.

Ricklefs, R. E., \& Relyea, R. (2013). Ecology: The economy of nature. WH Freeman.

Römer, U. (2006) (Herausg.): Cichlid Atlas 2: Natural History of South American Dwarf Cichlids. Volume 2. Mergus Verlag. 
Acta of Fisheries and Aquatic Resources

Silva, G.C., Castro, A.C.L. \& Gubiani, E.A. (2005). Estrutura populacional e indicadores reprodutivos de Scomberomorus brasiliensis Collette, Russo \& Zavala-Camin, 1978 (Perciformes: Scombridae) no litoral ocidental maranhense. Acta Scientiarum Biol. Sc., 27(4): 383-389.

Silva-Júnior, M.G., Castro, A.C.L., Soares, L.S. \& França, V.L. (2007). Relação peso-comprimento de espécies de peixes do estuário do rio Paciência da ilha do Maranhão, Brasil. Bol. Lab. Hidrobiol., 20(1): 31-38.

Schmidt, K., Andrade, M.C., Jesus, A.J.S., Araujo, J.S., Santos,P.R.B. \& Giarrizzo, T. (2015).Length-weight relationships for fish fauna from water bodies in the upper Tapajós river basin of Palito Mountain ridge, Brazilian Amazon region. Biota Amazônia, 5(3): 112-114

Vazzoler, A. E. A. M. (1996). Biologia da reprodução de peixes teleósteos: teoria e prática. Maringá: EDUEM/SBI/CNPq/Nupélia,

Winemiller, K. O., A. A. Agostinho \& E. P. Caramaschi (2008). Fish ecology in tropical streams, pp. 107146. In: Dudgeon, D. (Ed.). Tropical stream ecology. Amsterdam: Academic Press. 